\title{
EngagedScholarship@CSU
}

Philosophy \& Comparative Religion Department Faculty Publications

9-2016

\section{Intention and Moral Enhancement}

William Simkulet

Cleveland State University, w.simkulet@csuohio.edu

Follow this and additional works at: https://engagedscholarship.csuohio.edu/clphil_facpub

Part of the Bioethics and Medical Ethics Commons, and the Philosophy Commons

How does access to this work benefit you? Let us know!

\section{Publisher's Statement}

Copyright Wiley Online Library. This article first appeared in Bioethics, (9), 714. doi:10.1111/

bioe.12284. http://onlinelibrary.wiley.com/doi/10.1111/bioe.12284/abstract

\section{Original Citation}

Simkulet, W. (2016). Intention and Moral Enhancement. Bioethics, (9), 714. doi:10.1111/bioe.12284

This Article is brought to you for free and open access by the Philosophy \& Comparative Religion Department at EngagedScholarship@CSU. It has been accepted for inclusion in Philosophy \& Comparative Religion Department Faculty Publications by an authorized administrator of EngagedScholarship@CSU. For more information, please contact library.es@csuohio.edu. 


\title{
INTENTION AND MORAL ENHANCEMENT
}

\author{
WILLIAM SIMKULET
}

\begin{abstract}
Recently philosophers have proposed a wide variety of interventions referred to as 'moral enhancements'. Some of these interventions are concemed with helping individuals make more inforned decisions; others, however, are designed to compel people to act as the intervener sees fit Somewhere between these two extremes lie interventions designed to direct an agent's attention either towards morally relevant issues - hat-hanging -or away from temptations to do wrong - hathiding. I argue that these interventions fail to constitute genuine moral enhancement because, although they may result in more desirable outcomes - more altruism, more law-following, andlor less self-destructive behavior, they ignore a person's intentions, andoften what makes an action right or wrong is the intent behind it.
\end{abstract}

\begin{abstract}
Keywords
moral enhancement, moral bioenhancement, neuroenhancement, moral compulsion, hat-hanging, hat-hiding, intention
\end{abstract}

Sometimes people do the wrong thing. Recently philosophers have proposed a variety of interventions designed to help people avoid doing the wrong thing: some propose cognitive enhancement as a means of giving people the tools to make morally informed choices ${ }^{1}$ and others propose forcing agents to act to bring about their desired outcomes. ${ }^{2}$

${ }^{1}$ F. Jotterand. 'Virtue engineering' and moral agency: Will post humans still need the virtues? AJOB Neurascience 2011; 2(4): 3 9; J.A. Carter and E.C. Gordon. On Cognitive and Moral Enhancement: A Reply to Savulescu and Persson. Bioethics 2015; 29(3): 153 161; J. Harris(a). Moral Enhanœment and Freedom. Bioethics 2011; 25(2): 102 111; J. Harris(b). 'Ethics is for Bad Guys!' Putting the 'Moral' into Moral Enhancement. Bioethics 2013; 27(3): 169 173; J. Harris(c). Moral Progress and Moral Enhancement. Bioethics 2013; 27(5): 285 290; J. Harris and J. Savulescu. A Debate about Moral Enhanœment. Cam $Q$ Healhc Ethics 2015; 24(1): 8 22; O. Lev. Enhancing the Capacity for Moral Agency. AJOB Netaosicence 201 2; 3(4): 20 22; W. Simkulet. On Moral Enhancement. AJOB Neurosci 2012;3(4): 1718.

2 D. DeGrazia. Moral enhanoement, froedom, and what we (should) value in moral behaviour. $J$ Med Ethics 2014; 40(6): 361 368; T. Douglas Moral Enhancement. J Appl Philos 2008; 25(3): 228 245; T. Douglas. Moral Enhance ment via Emotion Modulation: A Reply to Haris Bioethics 2013; 27(3): 160 168; T. Douglas Enhancing Moral Conformity and Enhancing Moral Worth. Nerooethics 2014; 7(1): 75 91; T. Douglas. The Harms of Enhancernentand the Conclusive Reasons View. Cam Q Healthc Ethics 201 5; 24(1): 23 36; I Hughes Moral Enhancement Requires Multiple Virtues Ccon $Q$ Hualthc Ethics 2015; 24(1): 86 95; J. Savulescu \& I. Persson. Moral Enhanoement, Froedom, and the God Machine. Monist 2012; 95(3): 399 421; I Savulescu\& A. Sandberg. Neuro enhancement of Love and Marnage: The Chemicals Between Us. Netroethics 2008; 1(1) 31 44; I. Persson and I Savulescu The Perils of Cognitive Enhance ment and the Urgent Imperative to Enhance the Moral Character of Humanity. $J$ App Philos 2008; 25(3): 162 177; IR. Shoo. Neuroethics and the possible types of moral enhancement. AJOB Nezrasci 2012; 3(4):3 15.
Raus et al. call interventions of the first kind 'capacitiesoriented $^{3}$ and they are consistent with what Harris Wiseman calls a 'strong' conception of moral functioning, ${ }^{4}$ while Raus et al. call interventions of the latter kind 'behaviororiented', concerned with outcomes and consistent with what Wiseman calls a 'minimal' conception of moral functioning.

Each party refers to their proposed interventions as forms of 'moral enhancement', but in many of these cases the term is being applied too broadly. It would be absurd to say that any intervention to a person that results in desirable outcomes has morally enhanced that person. Consider the warlord who is on his way to burn down your village. You might intervene by offering him a regular bribe should he spare your village, resulting in the desirable outcome of your village being spared. Suppose the warlord takes you up on the offer and honors his agreement. Your village is spared a good outcome but it doesn't make sense to say that the warlord has been morally enhanced. Suppose we could obtain the same good outcome by giving the warlord a drug that made thoughts of sparing your village appealing, or by implanting a device in his head that would put him to sleep whenever he thought about your

${ }^{3}$ K. Raus, F. Focquaert, M. Schermer, J. Specker, and S. Sterckx. On defining moral enhancement, a clarificatory taxonomy. Neuroethics 2014; 7(3): 263273.

${ }^{4} \mathrm{H}$. Wiseman. Moral Enhancement 'Hard' and 'Soft' Forms. Am J Bioeth 2014; 14(4): 4849. 
village. These interventions, too, result in the same good outcome, but fail to make the warlord a better person. If anything, they make him a less successful warlord.

In some cases the interventions proposed by philosophers do not enhance the subject's ability to engage in moral behavior, but rather circumvent the ability. Consider the 'God Machine' proposed by Julian Savulescu and Ingmar Persson, a machine that would have the power to intervene whenever it detected that someone made a free choice contrary to the ones approved of by the machine; the machine would then edit the person's mind so that she was causally determined to act in an acceptable manner and so that she believed doing do was her choice to begin with. ${ }^{5}$ Savulescue and Persson claim 'the God Machine is not itself moral enhancement, ${ }^{6}$ yet it meets the behavior-oriented account of moral enhancement. Rather than improve the subject's moral character or motivation, the God Machine circumvents her ability to make decisions for herself. It has been argued that interventions like these are not enhancement, but moral compulsion, forcing others to act as one sees fit. ${ }^{7}$ Such compulsion might be acceptable in some situations, -for example restraining someone to prevent her from harming herself or others - but this doesn't seem like it should fall under the guise of 'moral enhancement'.

Two other forms of intervention are often proposed as candidates for moral enhancement: (1) interventions that prompt agents to pay attention to relevant moral issues, what I call hat-hanging, and (2) interventions that reduce the availability of prompts that might lead to immoral behavior, what I call hat-hiding. Although such interventions may result in desirable outcomes and don't face the bevy of criticisms that trouble moral compulsion, here I argue that hat-hanging and hat-hiding are not forms of moral enhancement. Make no mistake; such interventions are often morally acceptable, but they do not make their targets better people.

This article is divided into three sections. In the first section I construct a case of what I call hat-hanging, and then define hat-hanging and hat-hiding. In the second section I examine a variety of interventions philosophers have proposed as forms of moral enhancement that are cases of hat-hanging or hat-hiding. In the last section I argue that hat-hanging and hat-hiding fail to constitute genuine moral enhancement because they do not change the agent's intentions. An agent's intentions play a large part in determining whether her actions are morally right or wrong independent of the outcomes of these actions, and thus hat-hanging and hat-hiding do not influence an agent's moral character.

\footnotetext{
${ }^{5}$ Savulescu and Persson, op. cit. note 2.

${ }^{6}$ Ibid.

${ }^{7}$ Harris 2011, 2013a, 2013b; Harris and Savulescu 2015; Simkulet 2012, op. cit. note 1 .
}

\section{HANGING A HAT ON SOMETHING}

One night Jones's cousin dies tragically, and Jones believes that the right thing to do is to honor his cousin. Suppose that he has good reasons to believe that honoring his cousin involves thinking about him often. James Rachels argues that acting morally is a matter of doing what one has the best reasons to do $;^{8}$ as such Jones ought to think about his cousin often to honor him. Despite his believing he is morally obligated to think of his cousin, a week goes by and Jones does not think of him at all - until he receives a call about his cousin's funeral. Panicked that he is failing his moral obligations, Jones brainstorms and comes up with a variety of methods to force himself to think of his cousin:

(1) Jones prints off photos of his cousin and hangs them around his home on his refrigerator, next to his alarm clock, above his television, etc. Every morning as he wakes up, gets breakfast, and turns on the news he is prompted to think of his cousin.

(2) Jones ties a string to his finger. Every time he notices the string, he is prompted to think of the string, and often tries to remember why he tied it. When he successfully remembers, he thinks of his cousin.

(3) Jones has a screen implanted in front of his left eye that routinely displays pictures of his cousin. Whenever a picture is displayed, he believes that he will consciously or subconsciously think about his cousin.

(4) Jones begins writing a novel about his cousin's life. A poor writer, Jones is confident that he will need to revise the novel often, and each time he does so he believes he'll think of his cousin.

Jones believes these methods will cause him to think of his cousin, which he believes will satisfy his moral obligation to honor his cousin. Each method seems to satisfy a behavior-oriented conception of moral enhancement, but although such interventions might lead to the kind of behavior Jones wants to engage in, it's not clear that Jones becomes a better person by engaging in them.

These methods are instances of hanging a hat on something, where an action is hat-hanging if and only if it (1) draws attention to something and (2) depends on that something to achieve a goal. When he employs each of these methods, Jones intervenes in his normal life by drawing his attention in such a way that he believes will lead to the desired, morally required outcome: thinking about his cousin. Furthermore, Jones depends upon these interventions to bring about this outcome. Jones doesn't try to think about his cousin on his own, instead

8 J. Rachels. 2003. The Elements of Moral Philosophy. 4th edition. New York: McGraw Hill. 
he relies upon these methods to cause him to think of his cousin without any further effort on his part.

Jones' actions here are not alien; most of us engage in instances of hat-hanging quite regularly. For example, many of us set an alarm clock to wake us in the morning knowing full well that if the alarm clock somehow failed to ring at the appropriate time, we might fail to wake. The alarm clock's ringing draws our attention to the time and prompts us to start our day, and many of us depend upon it.

While hat-hanging involves drawing our attention to something, hat-hiding involves (1) drawing attention away from something and (2) depending on this subverted attention to achieve a goal. Hat-hiding, too, can result in improved behavior. Someone trying to lose weight might hide their fatty foods, thinking 'out of sight, out of mind.' This behavior doesn't make it impossible for the person to eat fatty foods, it just reduces their opportunities to be tempted, making it less likely they will eat fatty foods.

Both hat-hanging and hat-hiding involve changing the number of prompts one has with a goal of leading to more desirable behavior, but when one engages in these actions they often rely upon the addition or removal of prompts to do the 'moral work' and produce the more desirable outcomes. Neither hat-hanging or hat-hiding strengthen a person's will do the right thing. The appeal of such methods is that once they have been set up, they relieve the agent of having to do anything else. The hathanging or hat-hiding will typically cause them to behave more desirably without additional effort on their part.

One could argue that some instances of hat-hanging and hat-hiding are instrumentally valuable insofar as they train the person to become a better person. For example, if you set your alarm clock to 6am every day, eventually you might condition yourself to wake up at 6am without the alarm. However, if your only goal in setting your alarm is to make sure that you wake up on time, the conditioning is accidental. The person who hangs his hat on his alarm to wake himself believes that if the power goes out, he will not be awoken. If he has unwittingly conditioned himself to wake at $6 \mathrm{am}$, and power goes out, he will still wake up on time but this is a happy accident and unintentional.

\section{INTERVENTIONS}

A number of philosophers have proposed interventions that fall under the category of hat-hanging. Thomas Douglas contends moral enhancement is any intervention expected to leave the individual with morally better motives or behavior, ${ }^{9}$ and proposes the following case that satisfies the latter part of this description:

${ }^{9}$ Douglas 2014, op. cit. note 2.
Bryony is wealthy and believes she ought to do more to help the poor. Although she occasionally does something to help, she is generally unsympathetic to the poor. To help change her behavior, she sets up her television to display graphic images of the effects of poverty for brief periods that she does not consciously recognize, but that cause her subliminally to increase her feelings of sympathy to the poor. These increased feelings of sympathy prompt her to donate more money to charity. ${ }^{10}$

We're told Bryony believes that she ought to do more to help the poor. She is wealthy and has the means to help the poor. Yet she fails to do this, seemingly because of a weakness of will. For Douglas, Bryony doesn't have any psychological or physical impediments to doing the right thing; she is not depressed, easily distracted, psychopathic, too physically exhausted to act, etc. Bryony knows that she has a moral obligation that she's inexplicably unwilling to decide to fulfill on her own, so she hangs her hat on a plan to circumvent her otherwise normal decision making method, jury-rigging herself into doing what she, by stipulation, already believes is morally required of her.

Similarly, Julian Savulescu and John Harris discuss the possibility of interventions that would raise an agent's empathy ${ }^{11}$ and John Shook has proposed raising an agent's thoughtfulness about doing moral things and/or raising a person's sensitivity to the moral features of situations. ${ }^{12}$ Such interventions are designed to get the agents to do the right thing solely by drawing their attention to the thing that needs to be done.

Many philosophers also support hat-hiding interventions. A number of philosophers talk about 'chemical castration' or 'hormonal castration' as a means of preventing future sexual misbehavior by suppressing or removing a subject's sexual impulses. ${ }^{13}$

Julian Savulescu and Ingmar Persson propose a biomedical intervention that could reduce discrimination based on race. ${ }^{14}$ They contend that people automatically and necessarily catalog the race of each person they encounter, but that if an intervention could suppress this cataloging, then people would simply not be given the opportunity to discriminate based on race. Thomas Douglas imagines a similar case, in which a doctor, Andrew, who discriminates against his patients based on race takes steps to treat his patients equally by suppressing the neural connections associated with his racism. ${ }^{15}$

\footnotetext{
${ }^{10}$ Adapted from Douglas, op. cit. note 2, Harris 2013, op. cit. note 1.

${ }^{11}$ Harris and Savulescu, op. cit. note 1.

12 Shook, op. cit. note 2.

${ }^{13}$ Harris and Savulescu, op. cit. note 1, Douglas 2015, Savulescue and Sandberg, op. cit. note 2 .

${ }^{14}$ Savulescu and Persson, op. cit., note 2.

${ }^{15}$ Ibid.
} 
James Hughes notes that bariatric surgery is the most effective form of weight control, and that drugs and devices that suppress appetite might be similarly effective. ${ }^{16}$ Insofar as we have a moral obligation to stay healthy, this kind of hat-hiding seems to satisfy behaviororiented accounts of moral enhancement. Thomas Douglas suggests that moral enhancement might consist of suppressing 'counter-moral emotions: emotions that interfere with moral reasoning, sympathy, and all other plausible candidates for "morally good motives". ${ }^{17}$ John Doris suggests that we might modify our social institutions to avoid temptation, thus reducing people acting on said temptation. ${ }^{18}$ Similarly Neil Levy advocates combating cognitive biases by implementing social policies to shape our environments to dampen our cognitive weaknesses and increase our cognitive strengths. ${ }^{19}$

The key feature of each of these interventions is that they are designed to bring about desirable outcomes by either increasing prompts associated with good behavior, or decreasing prompts associated with bad behavior. Such interventions might be morally acceptable, but they don't seem to constitute genuine moral enhancement. This is to say that the people involved do not become better people as a result; their flaws persist but are just less obvious and less impactful.

Bryony suffers from akrasia, or weakness of will; she believes she has a strong moral obligation to help the poor and has every opportunity to do so... but she simply chooses not to act in the way she believes is right. She doesn't choose to do more to help the poor. However, she does choose to do something. She takes steps to make it more likely that she will help the poor in the future. She is prima facie praiseworthy for taking the steps that she believes are necessary to get her to do the right thing, in this case through subliminal conditioning, but this ignores the larger problem. Even after her intervention, she can still (1) know what the right thing to do is, and yet (2) not do it.

Similarly, while interventions designed to raise people's empathy or thoughtfulness about moral matters may result in said people acting in more morally desirable ways, it seems that they, like Bryony, are still akratic moral agents, unwilling to do the right thing unless they are constantly reminded. Like Bryony they do not do the right thing for the right reason; rather they might be inclined to do the right thing more often because they're prompted more often than others.

Cases of hat-hiding further seem to circumvent one's normal moral decision making method. In fact,

\footnotetext{
${ }^{16}$ Hughes, op. cit. note 2.

${ }^{17}$ Douglas, 2013, op. cit. note 2, p. 161.

18 J.M. Doris. 2002. Lack of character: Personality and Moral Behavior. Cambridge: Cambridge University Press.

${ }^{19}$ N. Levy. Ecological engineering: Reshaping our environments to achieve our goals. Philosophy \& Technology 2012; 25(4): 116.
}

advocates of such interventions seem to accept that their subjects can tell the difference between right and wrong, but that this alone isn't sufficient to get them to act rightly. Instead, they seek to remove the agent's opportunity to act wrongly. After all, one can't give in to temptation if one's not tempted. Sex offenders are given drugs to remove or suppress the temptation to sexually assault others; people who eat too much are given surgery and/ or drugs to control their weight because it is easier and more effective than relying upon them to fight their cravings; Julian Savulescu and Ingmar Persson propose drugs that would suppress an agent's ability to recognize the race of others, lest he be tempted to treat them unequally. Such interventions wouldn't enhance people morally; they just reduce bad outcomes and make those agents less obviously immoral. The chemically castrated sex offender, by assumption, is willing to sexually assault others if he feels like it; the person who underwent surgery is willing to eat more if he wasn't full; and the racist is still willing to let arbitrary traits he recognizes about others lead to preferential treatment if he takes note of such a trait. A sufficiently disinterested observer would be unable to tell the difference between a successfully medicated sex offender neighbor who refrains from sexually assaulting others and a neighbor that refrains from sexually assaulting others because she recognizes that such behavior, while biologically possible for her, would be morally horrible; despite this it is clear that there is a substantive moral difference between these neighbors. Much like shackles, hat-hiding interventions takes away opportunities an agent has to act immorally, but they don't make the person better. Such people are still threats to themselves and/or others given the chance.

\section{NO SHORTCUTS}

What is striking about the cases of Jones and Bryony is that both protagonists take it upon themselves to reject their normal way of making decisions which, they believe, have lead them to act immorally. Jones prompts himself to think of his cousin, while Bryony prompts her subconscious to think about the poor. Both cases seem to be instances of what Eddy Nahmias calls 'bypassing', the circumventing of normal moral deliberation processes in such a way that he contends would undermine the agent's normal moral responsibility for their actions. ${ }^{20}$ Of course in these cases Jones and Bryony are not merely puppets, but also the puppeteers, so it makes

${ }^{20}$ E. Nahmias, 2011. Intuitions about Free Will, Determinism, and Bypassing. in R. Kane, (ed.) The Oxford Handbook of Free Will 2nd Ed. Oxford University Press: 555 587; E. Nahmias, E. 2014. Is Free Will an Illusion? Confronting Challenges from the Modern Mind Sciences. In Moral Psychology, vol. 4, Free Will and Moral Responsibility. W. Sinnott Armstrong, Cambridge, MA; MIT Press: 125. 
sense to say that they are responsible for their free choices to pursue such interventions, but not what follows.

Jones and Bryony are uncontroversially morally responsible for their free choices to engage in hathanging; but is this behavior praiseworthy or blameworthy? If an agent has a moral obligation to perform some action $x$ and there is some other action $y$ that is necessary, but not sufficient for that agent performing $x$, then doing $y$ as a step to perform $x$ is praiseworthy. ${ }^{21}$ Both Jones and Bryony use hat-hanging as a step to do the right thing, but is it a necessary step? I think most of us would say 'no', that Jones is free to do what he thinks is right, to think about his cousin; and that Bryony is free to do what she thinks is right, act to benefit the poor. If they are free to do the right thing with no preparations, then hat-hanging is not necessary to bring about the desired results. As such, why would Jones and Bryony choose to jump through hoops to bring it about that they act morally in the future rather than just freely act to immediately bring about the same result?

In both cases Jones and Bryony are relying upon hathanging to causally determine them to do the right thing in the future, rather than freely choosing to do the right thing at the moment. At the very least this delaying of right action until the future is prima facie morally wrong. After all, Bryony could be out there helping the homeless now rather than MacGyvering her television to program herself to help the homeless in the future.

Although helping the poor is time-sensitive (better done sooner than later), Jones's moral obligation to honor his cousin doesn't seem to be. As such, one might be inclined to say that Jones's hat-hanging that causes him to think about his cousin is morally comparable to thinking about his cousin immediately. Furthermore, one could argue that by taking steps to make sure that he thinks of his cousin in the future, he is actually thinking about his cousin in the present, living up to his moral obligations. This, I think, is a mistake; resting upon an equivocation between (1) the action of thinking about Jones's cousin, and (2) Jones's moral obligation to think about his cousin to honor him. Jones believes that he ought to think about his cousin with the intent to honor him, but his hat-hanging only inadvertently involves thinking about his cousin; he doesn't think about his cousin to honor him, but rather he incidentally thinks about his cousin while he sets up prompts to cause him to think about his cousin in the future. What, then, about his future cousin-thinking, prompted by the photos he hung around the house, the string on his finger, the computer screen in his eye, and/or the novel he is writing? Although he's thinking about his cousin, he's

${ }^{21}$ W. Simkulet. On Robust Alternate Possibilities and the Tax Evasion Case. Southwest Philosophy Review 2015; 31(1), 101107. doing so for the wrong reason. He's not thinking of his cousin to honor him, he's thinking about his cousin because he set up a complex series of Rube Goldberg machines designed to prompt him to think about his cousin.

The same can be said for Bryony, she's not helping the poor because she believes she has a moral obligation to do so, she's helping the poor because she tricked herself into subconsciously feeling enough sympathy for the poor to get her to open her checkbook. She might just as easily trick herself into subconsciously feeling enough sympathy for unsuccessful, device-affected warlords to get her to open her checkbook so that they might get the troublesome devices removed so they can go back to sacking villages. For Jones, believing that his cousin is worthy of thinking about is not sufficient to get him to think about him, and for Bryony knowing that there are others who are in desperate need of help that she can provide is not enough to get her to help them. Both have a conception of what the right thing to do is, yet frustratingly fail to freely choose to do that thing, and instead freely take a shortcut designed to bring about an outcome that they are said to believe to be desirable. Yet in doing so, I contend, that they fail to do the right thing, because the right thing to do in any given situation is to do the thing you have the best reasons to do for those reasons.

Consider the following cases:

Hostage 1: Officer John arrives to find a violent, escaped criminal holding a hostage. He believes the hostage's life is in danger and shoots the criminal to save the hostage. He succeeds, the criminal dies, and the hostage is safe.

Hostage 2: Officer Joan arrives to find a violent, escaped criminal holding a hostage. She believes the hostage's life is in danger. As it so happens, Joan likes killing people and takes this opportunity to satisfy her bloodlust, knowing that her shooting of the criminal will appear like normal, responsible police work. She succeeds, the criminal dies, and the hostage is safe. ${ }^{22}$

Although both John and Joan act in the same way, they do so with different intentions. John's intentions are prima facie praiseworthy, while Joan's intentions are prima facie blameworthy. John does the right thing for the right reason, while Joan does the right thing for the wrong reason. As such, it makes sense to say that Joan acted immorally.

One might object to this position, contending that all that matters are the consequences of an action; in both

\footnotetext{
${ }^{22}$ Adapted from W. Simkulet. The Deontic Cycling Problem. Philosoph ical Analysis 2014; 31: 4964.
} 
of the above cases, the hostage is saved, so might we be inclined to say that both John and Joan have acted morally? I think not; suppose that both John and Jane were to accidentally post excepts from their personal journals online; with John's saying 'Today I had to shoot an escaped criminal to save a hostage. It wasn't fun, but I had to do it,' and Joan's saying 'Today I had the opportunity to shoot somebody. It was fun, I hope that more criminals escape and take hostages so that I can shoot them and get away with it.' I suspect many people would still say John's shooting was praiseworthy, but few would say that Joan's act was praiseworthy. Can we condemn Joan while still concluding that her action was morally praiseworthy? Again, I think not. Only moral agents can be morally responsible; actions themselves are neither praiseworthy or blameworthy. Of course we can conclude that Joan's action had good consequences and be happy that she took that action; but certainly we would much prefer that she was the sort of person who would act for better reasons. If Joan is the sort of person who kills when she can get away with it, she's the sort of person who would kill us if she could get away with it.

As with Joan, it makes sense to say that Jones and Bryony do the right thing for the wrong reasons. Rather than do what they recognize is morally right, Jones and Bryony attempt to bypass their own decision making processes to bring about the desired consequences. Observers might think that Bryony's actions are moral in the same way that the hostage might think Joan's actions were praiseworthy, but this is not the case.

Both Jones and Bryony had better options available. Instead of hat-hanging, they could have just chosen to do the right thing. Instead they chose to do the next best thing, tricking themselves into doing the right thing for the wrong reasons. This option is probably morally superior to complete inaction, but this freely choosing to do the second best option still constitutes a moral failing. Similarly, the other instances of hat-hanging and hathiding discussed in the last section seem to suffer from the same problem; they result in desirable outcomes with little to no effort from the subjects involved. Such interventions don't make them better people, they just rob them of some of their opportunities to act immorally. They key word here, of course, is 'some,' as the agents involved are still apt to fail moral challenges. Unfortunately, we are rarely in the position to tell the difference between someone who is genuinely a good person, and someone whose machinations have caused her to act in a way that appears identical to the way a good person would act.

Moral failing or not, does hat-hanging and/or hat-hiding constitute genuine moral enhancement? Hat-hanging, and hat-hiding alike would satisfy 'behavior-oriented' conceptions of moral enhancements, but then again so would the God machine and implanting the warlord with a chip that makes him fall asleep when he thinks about sacking your village. It doesn't make sense to call these interventions moral enhancement.

Only moral agents can be morally responsible, and they can only be responsible for things inside of their control. Hat-hanging, hat-hiding, and the like remove an agent's control over what they do, bypassing the normal free choices that most of us believe are within our control. In light of this, it seems that we should reject the behavior-oriented account in favor of the capacitiesoriented account. As interventions designed to force an agent to act as the intervener desires would undermine agency and responsibility, the only interventions that could reasonably be called moral enhancement would be interventions that enhance cognitive capacities in a way that would allow to them make morally better choices. For example, education may allow an agent to make more informed choices, and more informed choices are more likely to bring about the desired results. An educated moral agent who acts morally will have a greater chance at bringing about their desired result than an uneducated moral agent. By stipulation, the educated and uneducated moral agents who both do what they have the most reasons to do are morally praiseworthy; the difference that moral enhancement makes is not in how praiseworthy they are, but rather in how successful they are. All else being equal, the educated moral agent is more likely to bring about his morally desired outcomes than the uneducated moral agent. Both capacitiesoriented and behavior-oriented accounts of moral enhancement are designed to lead to morally desirable outcomes; the relevant difference is that while behaviororiented interventions do not concern themselves with bettering the agent, often merely bypassing the agent, capacities-oriented interventions do better the agent, making them more successful moral agents.

Consider two former warlords, the first implanted with a device that bypasses his free will and compels him to volunteer his time helping the homeless, and the second who took to reading philosophy and concluded that he would be happier, healthier, wealthier, and safer if he devoted his resources to improving his country rather than destroying it. Neither raid villages anymore. The difference, however, is that only the latter acts as a moral agent. Of course, the latter can still freely choose to go against his interests and raid villages; but all this is to say that he still has what George Harris calls the freedom to fall, or freedom to morally fail. ${ }^{23}$

In addition to education, it is possible that there are some biological interventions that may also count as moral enhancement; for example tools to help an agent say alert or focused may count as moral enhancement, as

${ }^{23}$ Harris 2011, op. cit. note 1, p. 103. 
would interventions designed to improve an agent's memory, cognitive abilities, or senses.

\section{CONCLUSION}

Here I've argued that hat-hanging and hat-hiding do not constitute genuine moral enhancement, where moral enhancement is concerned with giving individuals tools needed to better achieve their goals. The right thing to do is to do what one has the best reasons to do for those reasons; moral enhancement is any intervention that allows an agent to better evaluate reasons, and/or better achieve their goals. Although hat-hanging and hat-hiding do not constitute genuine moral enhancement, there are many situations in which such actions are morally acceptable, even morally obligatory. After all, it would be quite absurd to conclude that setting one's alarm clock is immoral... just as it would be quite absurd to conclude that setting one's alarm clock is moral enhancement and makes one a better person.

But this is not merely a matter of semantics; acts of hat-hanging and hat-hiding often bypass an agent's normal deliberation process, undermining their moral responsibility and robbing them of the freedom to choose how to live their lives. Although individuals such as Jones and Bryony should have the freedom to freely choose to undermine their own freedoms, it is prima facie morally undesirable to rob another of the ability to make their own free choices. The taking away of an agent's free will is one of the greatest harms that can befall a person think of the harm done to a prisoner sentenced to life in prison for a crime she did not commit, or a victim kept in a medically induced coma by a medically savvy kidnapper (the latter autonomy violation is more severe than the former, as it robs the agent of more of their autonomy; although the former comes with additional challenges). Those who advocate hat-hanging or hat-hiding interventions be performed on others against their will would have to show two things (1) that the benefits of such interventions outweigh harm, and (2) that the performing the interventions do not violate the agent's rights. 